International Journal of Linguistics, Literature and Translation (IJLLT)

ISSN: 2617-0299 (Online); ISSN: 2708-0099 (Print)

DOI: $10.32996 / \mathrm{ijllt}$

Website: https://al-kindipublisher.com/index.php/ijllt

IJLLT

\title{
Multilingual Analysis of Macrostructure in Online Lower Court Judgments of England and Wales, Germany, France and Spain: A Comparative Summary and Phraseology
}

Mr. Francisco Godoy Tena (PhD)

Profesor Asociado, Department of English Philology, Faculty of Arts and Humanities, Universidad Autónoma de Madrid, Spain.

Corresponding Author: Mr. Francisco Godoy Tena, E-mail: f.godoy@uam.es

ARTICLE INFORMATION

Received: September 11, 2020

Accepted: October 20, 2020

Volume: 3

Issue: 10

DOI: 10.32996/ijltt.2020.3.10.15

\section{KEYWORDS}

Court judgments, Macrostructure, England and Wales, Germany,

France, Spain, legal system, comparative study, phraseology, corpus analysis

\section{ABSTRACT}

Court judgments are documents in legal proceedings, defined as: "a court's final determination of the rights and obligations of the parties in a case" (Garner, 2006: 388). The main importance of this legal document lies in the fact that it covers all private and public problems that may arise in society. Owing to this fact, court judgments can be found in most of the legal systems worldwide. The aim of this article is to establish a comparative study of court judgments from four legal systems and written in the following languages: English, German, French and Spanish. This paper is focused on the macrostructural structure of court judgments in four legal systems: England and Wales, Germany, France and Spain. Thanks to this contrastive analysis, we may establish some patterns in court judgments written in four languages and issued in four different legal systems in order to set some patterns that would be appropriate for legal professionals, translators and interpreters, linguistics, and other academic experts. This digital corpus is composed of 60 multilingual court judgments: 15 of England and Wales, 15 of Germany, 15 of France, and 15 of Spain, issued recently (between the years 2019 and 2020) from different lower courts of these four legal systems. This study includes an internal analysis of the structure observed in all the court judgments, main terminology in the four languages with a brief explanation in English and the common phraseology in every court judgment of our multilingual corpus. This paper also includes the masculine and feminine forms in German, French and Spanish nouns, such as the French noun "Demand-eur [masculine] /-euse [feminine]". Thanks to these findings, we may find some linguistic parameters for experts to understand these essential court documents, how to compare their linguistic similarities and how to overcome the main linguistic differences of court judgments in these languages in order to make this study practical in several disciplines, such as foreign language teaching, specialized translation of comparative law, among many others.

\section{Introduction: Court Judgements}

This research studies the main feature of court judgments from four legal systems: England and Wales, France, Germany and Spain. The main aim of this study is twofold:

a. To find similarities and differences in court judgments from those legal systems.

b. To find usual phraseology from those legal documents that may help their correct understanding.

For practical purposes, the internal structure of all the court judgments has been divided into three sections: Heading, Main Body and Closure (Godoy, 2017). The Heading is the first section and it comprises the initial information in every court judgment, and it precedes the Main Body of the document. The Main Body constitutes the principal section of the court

AL-KINDI CENTER

K C AL-KINDI CENTER $\mathbf{R}$ DEVELOPMENT

Your gateway to world-class research
Published by Al-KindiCenter for Research and Development. Copyright (c) the author(s). This is an open access article under CC BY license (https://creativecommons.org/licenses/by/4.0/) 
judgments in the digital corpus: it covers several aspects of the court judgment: description of the case, case parties, legislation, precedent when needed, witness statements, and the ration decidendi, which shapes the Judge's precedent reasoning. Finally, all the court judgments finish with a Closure, which includes some further details of the case and the resolution.

\section{Literature Review}

Court judgments constitute important legal documents that have been the research study of some experts. We can mention some of the most recent studies:

Court judgments are essential in every society, as we can observe in several studies from different countries. We may include Villamil (2008), who studies the structure of court judgments in Colombia, Holl (2011), who analysed German and Spanish divorce judgments and Chagoyán (2011) and her study of judgment structures in Mexico.

Court judgments have additional been considered in several studies with many perspectives. We may mention some recent researchers:

Nava (2010) conducts a study of Mexican court judgments in a linguistic direction, including several uses of court judgments, such as a Judge's resolution, a formal document and the importance of its language in a procedural speech act.

Kumar et al. (2013) take into consideration the importance, as this study does, of online database of court judgments. They include an analysis of court judgments and point out the complexity of court judgments and the importance in citation in these legal documents.

In a corpus-based study, we have some research done by Vázquez y del Árbol $(2014,2016)$, who used macrostructure in detail for translation purposes in several of her publications. Godoy (2017, 2019a, 2019b, 2019c) also studied thoroughly the macrostructural sections of British and Spanish online judgments issued from lower and higher courts in order to establish some distinctive patterns in four legal systems: England and Wales, Scotland, Northern Ireland and Spain.

Shulayeva et al. (2017) establish a focus on how to extract some legal information from multiple law reports. They contribute towards automated identification of legal principles and facts within common law citations. This automated-based study is also observed in Kachappilly and Wagh (2018), who include a study of the IR (Information Retrieval), an automatic tool to extract and filter irrelevant information.

Hunter (2015) has a different contribution to the study of court judgments. Her research is focused on feminism by using three methods: quantitative, qualitative and rewriting. Her detailed explanation of judgments in Australian courts by feminist judges gives another perspective of the study of these legal documents.

Following Hunter's research, we may mention Hunter and Rackley (2020), who continue the study of feminism in United Kingdom Supreme Court based on a huge database of over 570 court judgments. They analysed feminist perspective and how this may imply in the feminist debates and the United Kingdom Supreme Court.

Owing to this relevance, it is imperative to know its internal structure: its main parts and its recurrent sections and phraseology.

\section{Methodology}

This methodology has been based on 60 online court judgments: 15 from England and Wales, 15 from Germany, 15 from France and 15 from Spain. These legal documents have been compiled considering the four legal systems and their languages. This study was based on a thorough reading of recent court judgments (issued in the year 2020), a division of every document into three main macrostructural structures: Heading, Main Body and Closure and an explanation of similarities and differences of these documents.

This division is based on the theory of macrostructure developed by Van Dijk (1980a: v), who defined "macroestructure" as:

[a] higher-level semantic or conceptual structures that organize the 'local' microstructures of discourse, interaction, and their cognitive processing. They are distinguished from other global structures of a more schematic nature, which we call superstructure. These are, so to speak, the global 'form' of the macrostructural 'content'. 


\section{Result and Discussion}

The analysis of these 60 court judgments has shown some features that will be explained in the following sections.

\subsection{Heading}

The Heading in the court judgments from these four legal systems constitutes the beginning of the court judgments before the main content of the court judgment.

\section{A. England and Wales}

English and Welsh court judgments coming from the Magistrates' Court. Our study shows the following features

a. The United Kingdom coat of arms and the Heading "Judiciary of England and Wales". These two elements introduce the court judgments analysed, both at the top centre of the first page.

b. Court name and its location.

c. The name of both parties, the Claimant and the Defendant, both centred, and the date.

County Court judgments show some changes. Unlike in Magistrates' Court judgments, County Court documents include a case number [an alphanumerical code] at the top left or centred position.

\section{B. Germany}

German court judgments ["Entscheidung(en)"] of our digital corpus have a regular pattern in the whole document. German court judgments are strictly codified, among them in the following German legislations: § 13 Abs. $1 \mathrm{Nr} .4 \mathrm{ZPO}, \S 117 \mathrm{Abs}$. $2 \mathrm{Nr}$. 3 VwGO, § 136 Abs. 1 Nr. 4 SGG and $\S 105$ Abs. 2 Nr. 3 FGO².

German Headings, named as "Urteilskopf", previously named with the Latin name of Rubrum, or "heading or head (Kopf) of the judgment", include common information of court judgments. This section is clearly defined as follows:

Der Urteil enthält: die Eingangsformel „Im Namen des Volkes”, das Akztenzeichen, das Gericht, (...) seinen Spruchkörper (Kammer usw.), die Namen der mitwirkenden Richter, den Tag der Letzten mündlichen Verhandlung, die Bezeichnung der Parteien (...), Wohnort und Stellung im Verfahren.

(Creifelds et al., 2007: 1219)

Therefore, we may summarise the above explanation of the German fixed macrostructural pattern in English:

a. Acronym of the court name ("Gericht").

b. Location, division ("Kammer", divided into civil division, "Zivilkammer" and criminal division, "Stafkammer").

c. Date ("Entscheidungsdatum: [DD.MM.YYYY]").

d. Code number ("Aktenzeichen": [alphanumerical code]")

e. Type of document: ("Dokumenttyp").

f. Appropriate legislation[s] in each judgment ("Norm[en]").

\section{France}

The French court judgments ("jugements") analysed in the corpus show a common pattern with the Heading coming from other court judgments:

a. Court name (for example, "Tribunal administratif d[e] [city/town]).

b. Location and code number [alphanumerical code]

c. Date (audience / lecture du [date])"

d. Name of the parties ("demand-eur/-euse" and "defend-eur/eresse").

In addition, we may find the phraseology "(Jugement) prononce par (sa) mise a disposition au greffe (le [date])" at the very end of the first macrostructural section.

French court judgments from the Tribunal de Grande Instance are less stable. We may find the court name at the top left corner, code number, "assignation du [date]". The centre of these documents has the following information: "Jugement",

$2 \S$ Abs [Abschnitt]: section of a German act, Nr. [Nummer]: number. The following translations of German Codes are approximate: ZPO [Zivilprozessordnung]: Code of Civil Procedure, VwGO [Verwaltungsgerichtsordnung]: Administrative Court Proceedings, SGG [Sozialgerichtsgesetz]: Social Courts Act, and FGO [Finanzgerichtsordnung]: Code of Procedure of Fiscal Courts. 
"rendu(e) du [date]", name of the Judges, "demand-eur/-euse" (Claimant) and "defend-eur/eresse" (Defendant) and "débats", an optional part in some judgments that repeats the name of the Judges.

However, French court judgments from le Tribunal Administrative have a more fixed macrostructure. They start with some common elements: alphanumerical code, name of both parties ("demand-eur/-euse" and "defend-eur/eresse") and the date [top left column]. The top right section shows a common Heading in administrative tribunal: "Republique Française. Au nom de peuple française" ["French Republic. In the name of the French people"]. The last lines of the top right column show "le tribunal administrative de [city]" or "juge des référes":

\section{Spain}

Spanish court judgments ["sentencia(s)"] are more codified than court judgments coming from other legal systems, mainly those from England and Wales. This codification is set out mainly in section 209 of the Spanish Ley de Enjuiciamiento Civil.

All the Spanish court judgements analysed include a strictly codified Heading that may be summarised as follows:

a. Firstly, the Spanish coat of arms, top centre of the court judgments, followed by an identification code of the judgment, called "Número Identificador de la sentencia".

b. The court name and location (top left).

c. Another code "Número de Resolución" and the name of the Judge ("Nombre del Juez-/-a" or "Magistrad-o/-a").

The information in this part of all the Spanish court judgments incorporates repetitive structures, as we may find unchanged court judgment details, such as the court name, location, contact phone or fax numbers, address, with the addition of the court name translated in other Spanish official languages (Catalan, Basque or Galician). Spanish Headings finish with "en [location] a [date]".

The Heading pattern of the four legal systems may be summarised as follows:

Table 1. Macrostructure in the Heading of English and Welsh, German, French and Spanish Court judgments.

\begin{tabular}{|c|c|c|c|}
\hline $\begin{array}{l}\text { England and } \\
\text { Wales }\end{array}$ & Germany & France & Spain \\
\hline $\begin{array}{l}\text { [United Kingdom } \\
\text { Coat of Arms] } \\
\text { [Top centre] }\end{array}$ & --- & --- & [Spain Coat of Arms] \\
\hline $\begin{array}{l}\text { In the } \\
\text { [City/Town] } \\
\text { Magistrates' } \\
\text { Court / County } \\
\text { Court } \\
\text { (sitting at } \\
\text { [City/Town]) } \\
\text { [Magistrates' } \\
\text { and County } \\
\text { Courts] }\end{array}$ & $\begin{array}{l}\text { Gericht: } \\
\text { [Landgericht] } \\
\text { [City/Town]. } \\
\text { Zivilkammer }\end{array}$ & $\begin{array}{lr}\text { Tribunal } & \\
\text { Administratif } & d(e) \\
\text { [City/Town] } & \\
\text { Tribunal de } & \text { grande } \\
\text { instance } & d(e) \\
{[\text { Town/City] }} & \\
\text { [Ordinal number] } \\
\text { Chambre } \\
\text { [Top centre] }\end{array}$ & $\begin{array}{l}\text { Name of the Spanish Court } \\
\text { City/Town } \\
\text { [Top left] } \\
\begin{array}{l}\text { Sección: [número ordinal en } \\
\text { mayúscula] }\end{array}\end{array}$ \\
\hline \multirow[t]{2}{*}{$\begin{array}{l}\text { (Neutral Citation } \\
\text { Number) } \\
\text { [Top left] } \\
\text { Case Number } \\
\text { Alphanumerical } \\
\text { Code (not all the } \\
\text { judgments) }\end{array}$} & $\begin{array}{l}\text { Entscheidungsdatum: } \\
\text { [Date] } \\
\text { Aktenzeichen: } \\
\text { [Alphanumerical } \\
\text { code] }\end{array}$ & $\begin{array}{l}\text { № } \quad \text { RG } \\
\text { [alphanumerical } \\
\text { code] } \\
\text { [Top left] }\end{array}$ & $\begin{array}{l}\text { Código: [código numérico] } \\
\text { Código de sentencia / Número de } \\
\text { resolución: [código numérico] } \\
\text { [Left column] }\end{array}$ \\
\hline & Dokumenttyp: Urteil & & $\begin{array}{l}\text { Procedimiento: } \\
\text { [civil/penal/procedimiento }\end{array}$ \\
\hline
\end{tabular}




\begin{tabular}{|c|c|c|c|}
\hline--- & [Top left] & --- & $\begin{array}{l}\text { abreviado/procedimiento } \\
\text { ordinario/sumario/recurso...] } \\
\text { Tipo de resolución: Sentencia }\end{array}$ \\
\hline $\begin{array}{l}\text { [Name of the } \\
\text { Complainant] } \\
v \\
\text { [Name of the } \\
\text { Defendant] } \\
\text { [Magistrates' } \\
\text { Court] }\end{array}$ & $\begin{array}{l}\text { Des Herrn / Frau } \\
\text { [Name of the } \\
\text { Appellant } \\
\text { Complainant] } \\
\text { Gegen } \\
\begin{array}{l}\text { Des Herrn / Frau } \\
\text { [Name of the } \\
\text { Defendant] }\end{array}\end{array}$ & $\begin{array}{l}\text { Entre (M./ Mme) } \\
\text { [Name of the } \\
\text { Appellant } \\
\text { Complainant] } \\
\text { Et (M./Mme) [Name } \\
\text { of the Defendant] } \\
\text { [Top left] } \\
\text { Dans l'instance } \\
\text { opposant [bold, } \\
\text { underlined]: } \\
\text { (Demand-eur /-euse) } \\
\text { [Name] à [bold, underlined] } \\
\text { (Défend-eur /-ess) } \\
\text { [optional] [Name] }\end{array}$ & $\begin{array}{l}\text { [Name of the Appellant / } \\
\text { Complainant] } \\
\text { (Demandante / Querellante / } \\
\text { Recurrente / Denunciante) } \\
\text { Contra D./Da } \\
\text { [Name of the Defendant] } \\
\text { Demandado / Denunciado / } \\
\text { Acusado / Recurrido] [Name] }\end{array}$ \\
\hline $\begin{array}{l}\text { [Date] } \\
\text { [Magistrates' } \\
\text { and County } \\
\text { Court] }\end{array}$ & $\begin{array}{l}\text { gemäß } \S \text { [section] in } \\
\text { Verbindung mit } \\
\text { [section] [Legislative } \\
\text { Code] in der Fassung } \\
\text { der Bekanntmachung } \\
\text { vom [date] } \\
\text { ([Legislative Code]) } \\
\text { am [date] einstimmig } \\
\text { beschlossen: }\end{array}$ & $\begin{array}{l}\text { Jugement pronounce } \\
\text { le [date] par (sa) } \\
\text { mise au disposition } \\
\text { au greffe (le [date]) }\end{array}$ & $\begin{array}{l}\text { [Location], [date] } \\
{[\text { Name of the Judge (Juez-a/ }} \\
\text { Magistrad-o } /-a)]\end{array}$ \\
\hline
\end{tabular}

\subsection{Main Body}

The Main Body is the essential part of the court judgments and its structural complexity is one of the most visible characteristics of these legal documents. Owing to this reason, this paper summarises the main points observed in this macrostructural section.

\section{A. England and Wales}

The English Main Body of the court judgments is varied and with many macrostructural Headings. Unlike Germany or Spain, the Headings in English and Welsh courts do not have any pattern to be considered. We may, however, establish some patterns of Main Body from English and Welsh court judgments. They are summarised in the next points:

a) Introduction / The facts / The background

Instead, there is a rich variety of headings in the Main Body, which is mainly introduced by "introduction", "the facts" or "the background". This introductory section includes the subsequent information:

- Introduction of the previous case.

- Defendant's background and their charges.

b) The Context / The Evidence / Summary of Evidence / Defendant's Evidence / The Prosecution Evidence (or Case) / The Factual Evidence

- Witness statements.

- $\quad$ Expert evidence of the case. 
c) The Law / Legal Framework / The Relevant Legislation / Applicable Principles

- $\quad$ Legal framework.

- $\quad$ Legislation applicable to the case.

\section{B. Germany}

Unlike what we observe in England and Wales judgments, German judgments include the following fixed macrostructural sections:

\section{a) Tenor}

In German lower courts judgments, the first element is the "Tenor", which introduces the case. The main ideas included in this section are:

- $\quad$ A summary of the facts: a Kläger/-in (Plaintiff/Claimant) to the Beklagter/-in (Defendant) or a Gläubiger/-in (Creditor) to the Schuldner/-in (Debtor).

- The cost of the proceedings or lawsuit ("Verfahren") that the "Beklagter"/ "-in" has to pay.

b) Gründe / Tatbestand

This is the main introductory section of German judgments in Lower Courts.

(Tatbestand) ist der Teil, in dem die Klageanträge, die von den Parteien vorgetragenen oder vom Gericht festgestellten Tatsachen, die Beweisangebote und -ergebnisse sowie die für das Urteil wesentliche Prozessgeschichte nach gewissen Regeln dargestellt werden.

(Creifelds, 2007: 1137)

The above German explanation of "Tatbestand" clarifies that it is a part or section in which the claims that have lodged the court facts, evidence ("Beweisangebote") at court and the conclusion of the judgment, pursuant to the law.

The content of the Main Body is divided into sections, each of them with a Roman number. We may find the following information:

- Introduction of the case.

- $\quad$ Further description of it. Dates and more information.

- $\quad$ Introduction of the appropriate legislation (gemäß $\S$ / pursuant to [article number])

- $\quad$ Finally, what the Kläger/-in claims (beantragt) to the Beklagter/-in.

c) (Entscheidungsgründe)

This optional section appears in many of the German judgments analysed although the information included in it is sometimes included in the previous section (Gründe or Tatbestand).

- Description if the claim: if it is authorized (zulässig) or (un-)grounded ([nicht] begründet)

\section{France}

a) Les faits (- Objet du litige) // Le tribunal / Exposé du litige / Motifs de la decision [Tribunal de grande instance] (Introduction to the facts)

Under some Headings, such as "débats", "le tribunal", "sur l'action publique", the main bodies of French court judgments start with the date of the judgment ("par act du [date]"). They have "attendu que" as an introductory link, similar to "parce que, puisque". This Main Body includes, as it happens with the other legal systems, the main content of the court judgment.

In addition, French court judgments include legislation in the Main Body ("en application de / concernant I'article [article number]") without any distinctive Heading. This is a different aspect to other court judgments, such as Spanish or in some 
English court judgments, where we may find some specific Headings, such as "fundamentos de hecho" in Spanish judgments or "the law" in English and Welsh court judgments.

In the Main Body, French court judgments include additional court decisions ("...le Conseil constitutionnel dans sa decision..."), sentence or conviction ("condamnation") and the explanation of the claimants ("les demandeurs / demanderesse"). French judgments also include "sur (ce)...", such as "sur la demand de dommage..."

\section{Spain}

Spanish judgments are fixedly coded:

a) Antecedentes de hecho

- Legislation.

- Judgment costs.

- Previous information about the judgment.

- Final resolution.

b) Hechos probados

This second section of Spanish court judgments extends the facts included in the previous point.

- Details about the facts.

- Defendant's explanation.

c) Fundamentos de hecho / de derecho / / jurídicos / de hecho y derecho

- Additional comments.

- Evidence.

- Previous court judgments (precedent).

\subsection{Closure}

The Closure is the final and concluding macrostructural section of our corpus' court judgments. We include a descriptive explanation of the Closure of court judgments from the four legal systems analysed.

\section{A. England and Wales}

The closure of England and Wales court judgments includes the Judge's final resolution under some Headings, such as "conclusion" o "decision". The final part also gives some detail about the Defendant's report or costs, together with some annexes, date and the Judge's signature.

\section{B. Germany}

The final resolution of German court judgments in lower courts is not as clearly distinctive as other court judgments in our multilingual corpus. As a matter of fact, the Closure does not appear under a specific title, as it happens with Spanish, English and Welsh and French court judgments. The Judge's resolution is included in the last 3 parts of the German court documents, although it is mainly found in the last part of the judgment. It also includes the appropriate legislation ("im Sinne von [legislation]", "die Entscheidung folgt aus [legislation]", according to the legislation "gemä $\beta$ [legislation]", "behuhen auf [legislation]"), the costs ("Die Kostenentscheidung"). German court judgments conclude with some expressions, such as "die Kammer hat die Revision zugelassen", "die Revision ist wegen grundsätzlicher Bedeutung (§ [legislation]) für den Klager / die Klägerin zuzulassen”, "der Klage / die Klägerin hat die Kosten des erfolglosen Rechtsmittels zu tragen”.

\section{France}

French court judgments include "Par ces motifs" or "sur l'action publique" (le tribunal), with a common term used in this section: "relaxe" or acquittal, explained as follows: "decision par laquelle un tribunal correctionnel ou un tribunal de pólice renvoie des fins de la poursuite un prévenu, en le reconnaissant non coupable" (Rey and Rey-Debove, 2020: 2175). 
Finally, French judgments come to a close with two signatures: "le Greffier", defined as the "officier public préposé au greffe" (Rey and Rey-Debove, 2020: 1185) and "le Président".

\section{Spain}

Spanish court judgments start this final part with "Fallamos", which gives the judgment resolution. It also includes the costs (“costs"), appeal ("recurso de apelación") when appropriate.

The following chart includes the Closure structure from our four legal systems:

Table 2. Macrostructure in the Closure of English and Welsh, German, French and Spanish Court judgments.

\begin{tabular}{|c|c|c|c|}
\hline England and Wales & Germany & France & Spain \\
\hline $\begin{array}{l}\text { Final thoughts about } \\
\text { the investigation } \\
\text { Discussion } \\
\text { Summary } \\
\text { Concluding remarks } \\
\text { Afterword } \\
\text { Passing off } \\
\text { Disposition }\end{array}$ & $\begin{array}{l}\text { [No distinctive Closure } \\
\text { Heading] } \\
\text { [All judgments] }\end{array}$ & $\begin{array}{l}\text { Par ces motifs } \\
\text { [Underlined, } \\
\text { capitalized, bold] } \\
\text { [All the judgments] }\end{array}$ & $\begin{array}{l}\text { Fallo / Fallamos } \\
\text { [Capitalized, bold] }\end{array}$ \\
\hline $\begin{array}{l}\text { Annex } \\
\text { Postscript } \\
\text { Judicial dicta } \\
\text { Concurring remarks } \\
\text { Costs } \\
\text { Disposal: damages / } \\
\text { interest }\end{array}$ & & $\begin{array}{l}\text { Sur l'action publique: } \\
\text { RELAXE [name] } \\
\text { [Capitalized, bold] } \\
\text { Prononce [resolution] } \\
\text { Condamne [name and } \\
\text { their charges] }\end{array}$ & $\begin{array}{l}\text { [Date] } \\
\text { [Judge's name] } \\
\text { [Signature] }\end{array}$ \\
\hline & & $\begin{array}{l}\text { Le Greffier } \\
\text { [signature] } \\
\text { [bottom, left, bold] } \\
\text { Le Président } \\
\text { [signature] } \\
\text { [bottom, right, bold] }\end{array}$ & \\
\hline
\end{tabular}

\section{Conclusion}

Our study shows some conclusions related to the four legal systems analysed in this paper.

In all the legal systems we observe the following common Heading elements in this order:

a. Coat of arms (England and Wales and Spain).

b. Name of the Court, place, alphanumerical code (optional in some English and Welsh judgments) and date.

c. Name of the Complainant(s) and Defendant(s), with different names depending on the legal system and their corresponding language.

In addition, there exists a visible complexity in the Heading in French, German and, especially, Spanish judgments. English and Welsh Magistrates' Court judgments have a less complexity, but, as it happens with Spanish judgments, they tend to be more stable in their structure. French court judgments have a more complexity structure, except in the "Tribunal Administratif de 
[city]". Spanish Headings introduce most of the administrative information, as it happens with the other three legal systems, but it repeats some information, such as code numbers, court name and location. This is not the case in English and Welsh Headings and less frequent in French Headings.

The Main Body of all the legal systems is the essential part of the court judgments. It explains the main facts of the case, accurate description of the case (thanks to experts or witnesses), the legislation (law) and, when appropriate, other important court judgments that may be important to the case, especially in English and Welsh court judgments (the precedent).

On top of this, all the legal systems give importance to legislation in this macrostructural section, although this is more visible in German, French and Spanish judgments. In the first two systems, their legislations appear at the beginning of the judgment, while in Spanish judgments the legislation has a specific macrostructural Heading, named as "fundamentos de hecho". In English and Welsh judgments this is less fixed, even though we may find some sections named as "the law" or "legislation", both included in the Main Body of the judgments.

The Closure shows some common and distinctive features. There exists an independent and visible Closure in English and Welsh ("Discussion" / "Final Thoughts" /"Remarks", among others), Spanish court judgments ("Fallo" / "Fallamos") or French court judgments ("Prononce" or "Condamne"), but not in German court judgments, in which the resolution appears in the last part of the court judgments without any distinctive heading or title. In addition, Civil Law (French and Spanish) court judgments finish with signatures (President in the case of France, the Judge in its Spanish counterpart). Online court judgments from England and Wales or Germany do not include this final part after the Judge's resolution.

Finally, all the court judgments in the four legal systems studied may be divided into the next main ideas:

- Heading: introductory and administrative information of every court judgment: court name, (criminal / civil...) division, location, (alphanumerical) code number, name of the parties and date. Frequent structure in the four legal systems.

- Main Body: essential and descriptive explanation of the case. It may include facts, witness and expert statements, legislation and further information of the case. Strictly fixed in Spanish and German court judgments, with a more flexible structure in English and Welsh court judgments.

- Closure: concluding macrostructural section of court judgments. Judge's resolution. It may include annexes, concluding remarks. French and Spanish court judgments may finish with some administrative features, such as official signatures.

The final table shows the most important ideas in order to summarise the most important features of court systems (CJs) and some frequent terms coming from English and Welsh, German, French and Spanish lower court judgments.

This study of a multilingual corpus may be considered for future investigations in legal and court translation. Thanks to this study, academic experts may have a chance of comparing different legal systems in order to establish some linguistic patterns of this text. However, this study shows some linguistic restrictions, based on the individual idiosyncrasy of these four legal systems, which results in a complex, but rich variety of internal sections of court judgments.

The Main Body of this table, due to its length, summarises the macrostructural headings:

Table 3. Summarised Features of English and Welsh, German, French and Spanish Court judgments.

\begin{tabular}{|c|c|c|c|c|}
\hline MAIN FEATURES & $\begin{array}{l}\text { English and } \\
\text { Welsh CJs }\end{array}$ & German CJs & French CJs & Spanish CJs \\
\hline \multicolumn{5}{|c|}{ Heading } \\
\hline Stable Structure & Less complex & Complex & Complex & $\begin{array}{l}\text { Fixed but } \\
\text { complex } \\
\text { (repetition) }\end{array}$ \\
\hline Frequent Phraseology & $\begin{array}{l}\text { Complainant } \\
\text { vs Defendant } \\
\text { [Parties] }\end{array}$ & $\begin{array}{l}\text { Klager (m.)-Kläger-in (f.) } \\
\text { vs Beklagter (m.) - } \\
\text { Beklagterin (f.) [Parties] }\end{array}$ & $\begin{array}{l}\text { (Demand- } \\
\text { eur (m.) - } \\
\text { euse (f.) vs } \\
\text { Défend-eur }\end{array}$ & $\begin{array}{l}\text { Demandante } \\
\text { vs Demandad- } \\
\text { o (m.) - a (f.) }\end{array}$ \\
\hline
\end{tabular}




\begin{tabular}{|c|c|c|c|c|}
\hline & & & $\begin{array}{l}\text { (m.) - ess } \\
\text { (f.) [Parties] }\end{array}$ & [Parties] \\
\hline \multicolumn{5}{|c|}{ Main Body } \\
\hline Fixed Structure & $\begin{array}{l}\text { Highly } \\
\text { flexible. }\end{array}$ & Fixed. & Flexible. & Codified. Fixed. \\
\hline Legislation & $\begin{array}{l}\text { Important. } \\
\text { Included } \\
\text { under some } \\
\text { headings. }\end{array}$ & Important. & Important. & $\begin{array}{l}\text { Important. } \\
\text { Included under } \\
\text { a fixed } \\
\text { heading. }\end{array}$ \\
\hline Previous CJs & $\begin{array}{l}\text { Essential. } \\
\text { Precedent. }\end{array}$ & Important. & Important. & Important. \\
\hline Frequent Phraseology & $\begin{array}{l}\text { Introduction / } \\
\text { The facts / } \\
\text { The } \\
\text { background } \\
\text { The Context / } \\
\text { The Evidence } \\
\text { / Summary of } \\
\text { Evidence / } \\
\text { Defendant's } \\
\text { Evidence / } \\
\text { The } \\
\text { Prosecution } \\
\text { Evidence (or } \\
\text { Case) / The } \\
\text { Factual } \\
\text { Evidence } \\
\text { The Law / } \\
\text { Legal } \\
\text { Framework / } \\
\text { The Relevant } \\
\text { Legislation / } \\
\text { Applicable } \\
\text { Principles }\end{array}$ & $\begin{array}{l}\text { Tenor } \\
\text { Gründe / Tatbestand }\end{array}$ & $\begin{array}{l}\text { Les faits / } \\
\text { Objet du } \\
\text { litige } \\
\text { Le tribunal } \\
\text { / Exposé du } \\
\text { litige / } \\
\text { Motifs de la } \\
\text { decision }\end{array}$ & 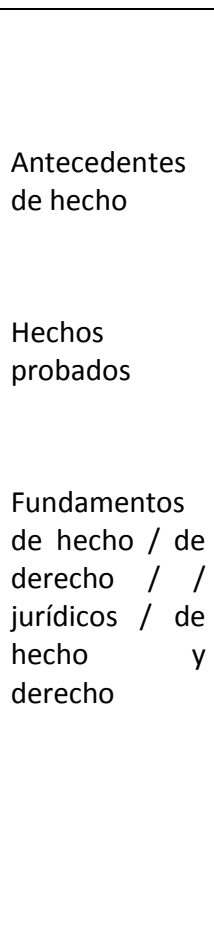 \\
\hline \multicolumn{5}{|c|}{ Closure } \\
\hline Fixed Structure & $\begin{array}{l}\text { Independent } \\
\text { heading }\end{array}$ & No independent heading & $\begin{array}{l}\text { Visible } \\
\text { section. }\end{array}$ & $\begin{array}{l}\text { Independent } \\
\text { heading. }\end{array}$ \\
\hline Frequent Phraseology & $\begin{array}{l}\text { Discussion, } \\
\text { Final } \\
\text { Thoughts, } \\
\text { Remarks }\end{array}$ & & $\begin{array}{l}\text { Prononce, } \\
\text { Condamne }\end{array}$ & Fallo, Fallamos \\
\hline Final Sections & $\begin{array}{l}\text { Final remarks, } \\
\text { Annex, Costs }\end{array}$ & $\begin{array}{c}\text { [included in the last part } \\
\text { of the Main Body] }\end{array}$ & Signatures & Signatures \\
\hline
\end{tabular}




\section{References}

[1] Chagoyán, L. (2011). Sobre la estructura de las sentencias en México: una visión crítica y una propuesta factible. Quid luris, 12. 63-94.

[2] Creifelds, C., Weber, K. and Guntz, D. (2007). Rechtswörterbuch. Munich: Beck.

[3] Garner, B. A (Ed.). Black's Law Dictionary. Dallas: Thomson/West.

[4] Godoy Tena, F. Análisis Macroestructural Comparado de un Corpus Digital Bilingüe (Inglés-Español) de 100 Sentencias Judiciales Británicas y Españolas de Primera Instancia y de Instancia Apelativa (2017). [PhD directed by Ms Esther Vázquez y del Árbol PhD]. Universidad Autónoma de Madrid.

[5] Godoy Tena, F. (2019a). Propuesta macroestructural de sentencias judiciales digitales de Irlanda del Norte en estudios universitarios especializados. European Journal of Foreign Language Teaching, 4 (3), 28-40.

[6] Godoy Tena, F. (2019b). Macrostructural Study of Digital Judgments from England and Wales. A Comparative Analysis. Modern Journal of Language Teaching Methods, 9 (3). https://doi.org/10.2307/3586733.

[7] Godoy Tena, F. (2019c). Extralinguist Elements in English and Welsh Court Judgments: Coat of Arms, Neutral Citation and Code Numbers. Modern Journal of Language Teaching Methods, 9 (10). http://dx.doi.org/10.26655/mjltm.2019.10.4.

[8] Holl, I. (2011). Die Konstrastive Textsorttenanalyse als Vostufe zur Übersetzung von Rechtstexten: Deutsche und Spanische Scheidungsurteile im Vergleich. Revista de Lingüistica y Lenguas Aplicadas, 6, 195-207. https://doi.org/10.4995/rlyla.2011.903.

[9] Hunter, R. (2015). Analysing Judgments from a Feminist Perspective. Legal Information Management, 15 (1), 8-11. https://doi.org/10.1017/S1472669615000067.

[10] Hunter, R. and Rackley, E. (2020). Feminist Judgments on the UK Supreme Court, Canadian Journal of Women and the Law, 32 (1), $85-$ 113. https://doi.org/10.3138/cjwl.32.1.04.

[11] Kachappilly, D. and Wagh, R. (2018). Similarity Analysis of Court Judgments using Clustering of Case Citation Data: a Study. International Journal of Engineering \& Technology, 7 (2), 855-858. https://10.14419/ijet.v7i2.9657.

[12] Kumar, S., Krishna Reddy, P., Reddy V. and Suri, M. (2013). Finding Similar Legal Judgments under Common Law System. Databases in Networked Information Systems: 8th International Workshop, 7813, 103-116. https://doi.org/10.1007/978-3-642-37134-9 9.

[13] Linguee (n.d.). Wörterbuch Englisch-Deutsch und Suche in einer Milliarde Übersetzungen. https://www.linguee.de/deutsch-englisch.

[14] Nava Gomar, S. O. (2010). La Sentencia como Palabra e Instrumento de la Comunicación", Revista Justicia Electoral. 1 (6), $48-50$.

[15] Rechtslexikon.net (n.d.). http://rechtslexikon.net/d/urteilsformel/urteilsformel.htm.

[16] Rey, A. and Rey-Debove, J. (2020). Le Petit Tobert. Dictionnaire alphabétique et analogique de la langue française. Paris: LeRobert.

[17] Shulayeva, O., Siddharthan, A. and Wyner, A. (2017). Recognizing Cited Facts and Principles in Legal Judgements. Artificial Intelligence Law, 25, 107-126. https://doi.org/10.1007/s10506-017-9197-6.

[18] Van Dijk, T. A. (1980). Macrostructures: An Interdisciplinary Study of Global Structures in Discourse, Interaction, and Cognition. Hillsdale: Lawrence Erlbaum.

[19] Vázquez y del Árbol, E. (2014). Los actos procesales: estudio macroestructural contrastivo (inglés-español) aplicado a la traducción. Fachsprache 3-4. 179-204. https://doi.org/10.24989/fs.v36i3-4.1391.

[20] Vázquez y del Árbol, E. (2016). Traducción judicial y policial (Inglés <> Español) y Derecho Comparado. Madrid: Dykinson. [21] Villamil Portilla, E. (2008). Estructura de la Sentencia Judicial. Bogotá: Consejo Superior de la Judicatura. 